\title{
Anthropometric measurements among four Asian countries in designing sitting and standing workstations
}

\author{
NURUL IZZAH ABD RAHMAN*, SITI ZAWIAH MD DAWAL, NUKMAN YUSOFF and \\ NABILLA SOFIA MOHD KAMIL \\ Department of Mechanical Engineering, Faculty of Engineering, University of Malaya, 50603 Kuala Lumpur, \\ Malaysia \\ e-mail: izzahrahman@um.edu.my; sitizawiahmd@um.edu.my; nukman@um.edu.my; \\ sofia_kamil@yahoo.com.my
}

MS received 5 September 2016; revised 24 May 2017; accepted 2 June 2017; published online 7 February 2018

\begin{abstract}
An anthropometric database for sitting and standing dimensions for Malaysian operators was developed based on the measurements from 146 male and 168 female participants (18-45 years old). The anthropometric data were subsequently compared to those from three selected Asian countries, focussing on the sitting and standing posture dimensions. Thirty-six anthropometric dimensions were selected for comparison based on common availability among the four countries. The results indicated that the Indonesians were the tallest (male: $172 \mathrm{~cm}$, female: $159 \mathrm{~cm}$ ) among the four countries, whereas the Filipinos were the shortest for both male and female (male: $167 \mathrm{~cm}$, female: $153.9 \mathrm{~cm}$ ). Filipinos and Malaysian data were almost similar and appear to have the smallest values for eye height (male: $155 \mathrm{~cm}$, female: $143 \mathrm{~cm}$ ) and elbow height (male: $104 \mathrm{~cm}$, female: $96 \mathrm{~cm}$ ). The knowledge of variations in the population is useful in designing sound workstations and facilities for the betterment of the industrial environment.
\end{abstract}

Keywords. Anthropometric; Asian; design; sitting; standing; workstation.

\section{Introduction}

Anthropometry is the science dealing with the physical measurements of the human individual, such as the person's size, form and functional capacities. Numerous efforts have been made to establish anthropometric database of various population groups, such as students, civilian, workers and military recruits [1-5]. These anthropometric data are utilised by the manufacturing community as a guideline in designing products for the global market [6-8]. Availability of country-specific anthropometric database allows the product to be designed ergonomically to fit the population of specific countries. Variability in human features relates to ethnicity, gender and age [9]. Ethnic diversity, which is more prominent among races rather than nations, is an important factor that influences anthropometric data. Furthermore, the same race coming from different nations may exhibit dissimilarity in body sizes due to variations in social and economic environments. It was suggested by Pheasant [10] that the variations in body dimensions of population groups can be highlighted in terms of the overall body size and bodily proportions. There are several distinctive anthropometric

*For correspondence dimensions that are noticeable when comparisons between ethnic and race groups are made, such as the mean stature and sitting height [11].

The Southeast Asian countries have strong relations and associations in terms of race, culture and history. In particular, the populations of Malaysia, Indonesia, Philippines and Thailand are geographically related based on their locations. Currently, no studies have been conducted to evaluate the differences in the anthropometric data of the countries in this region. Thus, this study aims to test a hypothesis that there are significant differences of body dimensions of Malaysian male and female. Secondly, this study aims to compare the differences in anthropometric dimensions of four Asian countries, namely Malaysia, Indonesia, Philippine and Thailand. This study will also highlight the variations in population dimensions required in the design of a sitting and a standing industrial workstation.

\section{Methods}

\subsection{Malaysian anthropometric database}

Ethical approval for the study was provided by the Medical Ethics Committee, University Malaya Medical Centre. In 
all, 146 male and 168 female healthy Malaysian subjects (aged 18-45 years) were selected to participate in this anthropometric study. The sample population was general, which consisted of students and workers of offices and factories. The sample size was estimated based on a study by Nurul Shahida et al [12] and $\mathrm{Hu}$ et al [13]. The number of subjects was estimated according to the equation given in Annex A of ISO 15535:2003 'General requirements for establishing anthropometric databases' based on a $95 \%$ confidence interval and 5th and 95th percentiles:

$$
n \geq(3.006 \times C V / \alpha)^{2}
$$

where $n$ is the sample size, $\mathrm{CV}$ is the coefficient of variation and $\alpha$ is the percentage of relative accuracy desired. The sample size was calculated based on the assumption that a relative accuracy of $10 \%$ is sufficient for the 5 th and 95 th percentiles and an empirical CV value of 25 . It was discovered that the minimum sample size for this study is 112
(56 subjects for each gender). Thus the number of subjects for this study, with the total number of 314 subjects, is sufficient.

The participants provided their written consent to participate in this study. Anthropometric measurements were taken based on Pheasant's [10] protocol using a standard professional anthropometry measuring set, a weighing scale, a measuring chair, a scientific Martin pelvimeter and a TTM bone caliper (TTM Martin's human body measuring kit; Mentone Educational Centre, Australia). These instruments were used to measure body segment lengths, heights, breadths, depths, circumferences and body weights. Anthropometric dimensions calculated from the recorded data include stature, sitting height, hand length and head circumference. The recorded data are subsequently filtered for extreme outliers, which were probably due to erroneous measurements and recordings. A statistical package (SPSS for windows, Version 23.0) was used to analyse the results.

Table 1. Anthropometric data for Malaysian males (all dimensions in $\mathrm{cm}$, body weight in $\mathrm{kg}$ ).

\begin{tabular}{|c|c|c|c|c|c|c|c|c|}
\hline No. & Anthropometric measurement & Mean & SD & $1 \%$ tile & $5 \%$ tile & $50 \%$ tile & $95 \%$ tile & $99 \%$ tile \\
\hline 1 & Weight & 68.4 & 13.4 & 44.0 & 53.0 & 66.0 & 94.8 & 104.5 \\
\hline 2 & Stature & 168.1 & 12.9 & 143.0 & 158.3 & 168.5 & 179.3 & 181.5 \\
\hline 3 & Standing eye height & 155.5 & 14.1 & 116.3 & 146.9 & 156.1 & 167.9 & 171.6 \\
\hline 4 & Standing shoulder height & 138.5 & 11.5 & 107.2 & 130.5 & 139.0 & 150.5 & 152.8 \\
\hline 5 & Standing elbow height & 103.7 & 9.4 & 81.0 & 96.1 & 103.7 & 112.6 & 132.4 \\
\hline 6 & Waist height & 99.1 & 9.7 & 68.2 & 91.6 & 99.8 & 109.1 & 111.0 \\
\hline 7 & Crotch height & 78.8 & 6.7 & 60.9 & 70.1 & 79.0 & 88.1 & 93.3 \\
\hline 8 & Kneecap height & 47.0 & 3.5 & 40.4 & 41.9 & 46.8 & 52.3 & 55.4 \\
\hline 9 & Coat height, standing & 68.8 & 9.5 & 49.8 & 56.0 & 68.0 & 81.8 & 85.4 \\
\hline 10 & Span & 169.9 & 15.5 & 117.4 & 158.4 & 170.5 & 184.2 & 189.8 \\
\hline 11 & Elbow span & 85.9 & 9.3 & 66.7 & 75.6 & 86.5 & 96.3 & 105.9 \\
\hline 12 & Hip breadth, standing & 37.2 & 38.1 & 25.8 & 28.8 & 32.5 & 37.5 & 150.8 \\
\hline 13 & Interscye breadth & 30.8 & 3.3 & 24.2 & 25.8 & 30.5 & 36.1 & 38.1 \\
\hline 14 & Back waist length & 46.6 & 4.7 & 36.6 & 38.2 & 46.5 & 54.7 & 59.3 \\
\hline 15 & Sleeve inseam & 45.9 & 8.2 & 35.6 & 37.5 & 44.4 & 65.7 & 72.6 \\
\hline 16 & Shoulder breadth & 40.0 & 5.0 & 29.5 & 31.4 & 41.0 & 47.1 & 49.5 \\
\hline 17 & Hip breadth, sitting & 34.3 & 3.9 & 24.5 & 29.1 & 34.1 & 40.8 & 45.3 \\
\hline 18 & Forearm-hand length & 39.5 & 9.5 & 23.1 & 24.0 & 44.4 & 49.0 & 50.6 \\
\hline 19 & Buttock-knee length & 54.4 & 3.6 & 46.0 & 48.2 & 54.4 & 59.7 & 61.7 \\
\hline 20 & Buttock-popliteal length & 43.0 & 3.8 & 34.0 & 36.5 & 43.3 & 49.1 & 50.3 \\
\hline 21 & Shoulder-elbow length & 34.9 & 3.2 & 28.4 & 30.3 & 34.8 & 38.7 & 42.4 \\
\hline 22 & Thigh clearance & 13.1 & 2.1 & 8.3 & 10.5 & 12.8 & 16.5 & 18.0 \\
\hline 23 & Arm reach forwards & 80.9 & 8.5 & 68.7 & 70.4 & 81.0 & 93.4 & 104.7 \\
\hline 24 & Arm reach upwards & 149.6 & 180.9 & 115.8 & 120.4 & 128.0 & 139.0 & 583.0 \\
\hline 25 & Sitting height & 87.7 & 4.5 & 76.6 & 80.8 & 87.4 & 95.2 & 97.4 \\
\hline 26 & Sitting eye height & 76.3 & 4.3 & 63.8 & 69.9 & 76.0 & 83.5 & 86.7 \\
\hline 27 & Sitting shoulder height & 59.3 & 3.8 & 51.6 & 53.8 & 59.1 & 66.1 & 68.3 \\
\hline 28 & Sitting elbow height & 23.1 & 3.7 & 15.5 & 17.4 & 23.1 & 29.9 & 30.4 \\
\hline 29 & Knee height & 50.4 & 4.9 & 42.6 & 44.6 & 50.7 & 56.6 & 59.2 \\
\hline 30 & Popliteal height & 42.4 & 4.4 & 34.9 & 37.9 & 42.8 & 46.8 & 49.7 \\
\hline 31 & Head length & 19.1 & 3.9 & 15.9 & 16.3 & 18.1 & 25.7 & 33.2 \\
\hline 32 & Head breadth & 15.2 & 1.0 & 12.7 & 13.8 & 15.4 & 16.8 & 17.1 \\
\hline 33 & Hand length & 18.3 & 1.1 & 15.7 & 16.5 & 18.2 & 19.9 & 20.5 \\
\hline 34 & Hand breadth & 8.1 & 0.8 & 6.6 & 7.0 & 8.1 & 9.6 & 10.4 \\
\hline 35 & Foot length & 24.7 & 1.3 & 21.9 & 22.8 & 24.7 & 26.7 & 27.5 \\
\hline 36 & Foot breadth & 9.6 & 0.7 & 7.9 & 8.4 & 9.6 & 10.6 & 11.3 \\
\hline
\end{tabular}


Table 2. Anthropometric data for Malaysian females (all dimensions in $\mathrm{cm}$, body weight in $\mathrm{kg}$ ).

\begin{tabular}{|c|c|c|c|c|c|c|c|c|}
\hline No. & Anthropometric measurement & Mean & SD & $1 \%$ tile & $5 \%$ tile & $50 \%$ tile & 95\%tile & $99 \%$ tile \\
\hline 1 & Weight & 58.7 & 14.1 & 40.0 & 42.7 & 55.8 & 81.0 & 103.1 \\
\hline 2 & Stature & 155.7 & 6.2 & 143.9 & 146.4 & 155.1 & 165.5 & 170.4 \\
\hline 3 & Standing eye height & 143.1 & 6.3 & 130.5 & 133.4 & 142.7 & 153.4 & 157.0 \\
\hline 4 & Standing shoulder height & 127.6 & 6.5 & 112.8 & 118.2 & 127.2 & 137.8 & 140.1 \\
\hline 5 & Standing elbow height & 96.2 & 4.6 & 86.4 & 89.4 & 96.3 & 103.8 & 106.5 \\
\hline 6 & Waist height & 93.1 & 4.5 & 83.3 & 86.6 & 93.1 & 101.0 & 102.8 \\
\hline 7 & Crotch height & 74.7 & 11.6 & 59.4 & 62.5 & 70.0 & 96.1 & 100.4 \\
\hline 8 & Kneecap height & 42.7 & 3.3 & 33.3 & 37.6 & 42.3 & 47.6 & 49.3 \\
\hline 9 & Coat height, standing & 64.1 & 18.8 & 56.0 & 56.2 & 60.7 & 68.4 & 135.8 \\
\hline 10 & Span & 155.0 & 9.1 & 134.5 & 143.2 & 155.9 & 165.6 & 171.9 \\
\hline 11 & Elbow span & 79.5 & 8.4 & 56.7 & 71.6 & 79.5 & 88.1 & 90.2 \\
\hline 12 & Hip breadth, standing & 32.8 & 3.7 & 27.1 & 28.0 & 32.0 & 37.9 & 46.0 \\
\hline 13 & Interscye breadth & 28.7 & 3.7 & 21.8 & 23.2 & 28.7 & 35.4 & 39.5 \\
\hline 14 & Back waist length & 40.2 & 4.3 & 30.1 & 33.2 & 40.0 & 48.4 & 50.0 \\
\hline 15 & Sleeve inseam & 43.4 & 4.9 & 34.0 & 36.1 & 43.3 & 51.6 & 53.4 \\
\hline 16 & Shoulder breadth & 37.9 & 3.6 & 26.3 & 33.9 & 37.6 & 42.4 & 48.7 \\
\hline 17 & Hip breadth, sitting & 35.3 & 4.1 & 28.1 & 30.0 & 34.6 & 42.0 & 49.9 \\
\hline 18 & Forearm-hand length & 39.8 & 6.5 & 22.1 & 24.9 & 41.2 & 45.3 & 47.5 \\
\hline 19 & Buttock-knee length & 52.5 & 4.7 & 33.2 & 47.0 & 53.0 & 58.5 & 60.3 \\
\hline 20 & Buttock-popliteal length & 43.1 & 3.8 & 33.3 & 37.1 & 43.0 & 49.2 & 52.0 \\
\hline 21 & Shoulder-elbow length & 32.2 & 3.1 & 26.1 & 28.5 & 32.1 & 35.1 & 42.6 \\
\hline 22 & Thigh clearance & 13.4 & 2.5 & 8.9 & 10.2 & 13.0 & 18.9 & 19.4 \\
\hline 23 & Arm reach forwards & 74.2 & 7.0 & 63.6 & 67.3 & 73.8 & 81.5 & 88.3 \\
\hline 24 & Arm reach upwards & 117.9 & 8.0 & 101.8 & 105.1 & 118.8 & 128.6 & 129.8 \\
\hline 25 & Sitting height & 81.5 & 4.5 & 73.0 & 75.9 & 81.5 & 87.5 & 89.9 \\
\hline 26 & Sitting eye height & 70.9 & 5.1 & 63.4 & 64.6 & 70.7 & 77.9 & 80.7 \\
\hline 27 & Sitting shoulder height & 54.5 & 4.7 & 42.4 & 49.0 & 54.4 & 60.5 & 64.8 \\
\hline 28 & Sitting elbow height & 23.1 & 3.2 & 17.7 & 19.0 & 22.9 & 29.0 & 30.6 \\
\hline 29 & Knee height & 47.5 & 3.7 & 36.1 & 41.8 & 48.0 & 52.7 & 55.5 \\
\hline 30 & Popliteal height & 40.0 & 3.4 & 29.3 & 34.0 & 40.2 & 44.3 & 47.3 \\
\hline 31 & Head length & 17.7 & 0.9 & 16.1 & 16.6 & 17.6 & 19.4 & 20.1 \\
\hline 32 & Head breadth & 15.0 & 1.0 & 13.3 & 13.5 & 15.0 & 16.4 & 17.7 \\
\hline 33 & Hand length & 17.0 & 0.8 & 15.2 & 15.9 & 17.0 & 18.2 & 19.0 \\
\hline 34 & Hand breadth & 7.2 & 0.5 & 6.3 & 6.4 & 7.1 & 8.0 & 8.5 \\
\hline 35 & Foot length & 22.7 & 1.2 & 20.4 & 20.9 & 22.5 & 25.0 & 25.5 \\
\hline 36 & Foot breadth & 8.9 & 1.0 & 7.4 & 8.0 & 8.8 & 10.0 & 12.7 \\
\hline
\end{tabular}

Thirty-six anthropometric dimensions (tables 1 and 2) were considered in the analysis. Comparison between male and female dimensions was analysed using $t$-test (table 3 ).

\subsection{Comparison of mean values for selected Asian countries}

The anthropometric databases for four Asian countries were chosen for comparison, which include previously published data for populations of Indonesia, Philippine and Thailand. The Indonesian anthropometric database was published by Chuan et al [14]. This database listed - 37 anthropometric dimensions obtained from 245 male and 132 female subjects from Indonesia within the age range of 18-45 years. The Filipinos anthropometric database includes measurements for standing, sitting, hand and foot dimensions, breadth and circumference of various body parts obtained from 1805 workers, with a majority (77\%) being below 30 years [15]. However, they are relatively shorter and smaller in stature compared with the general population of Filipinos. The anthropometric data for Thailand were adopted from the database published by a research working group involving 41 dimensions from 200 male and 200 female participants [16].

In this research, - 36 parameters are selected for comparison, chosen based on their common availability among the four population groups. Table 4 shows a comparison of the mean values for selected parameters of the population groups. It can be seen that there are differences in the mean values, indicating variations in the anthropometric dimensions between populations. This difference shows the 
Table 3. Analysis of $t$-test for Malaysian male and female.

\begin{tabular}{lrl}
\hline Anthropometric measurement & $t$-ratio & $p$-value \\
\hline Weight & 6.219 & $0.000^{*}$ \\
Stature & 0.453 & 0.651 \\
Standing eye height & 0.640 & 0.522 \\
Standing shoulder height & 7.809 & $0.000^{*}$ \\
Standing elbow height & 6.566 & $0.000^{*}$ \\
Waist height & 5.293 & $0.000^{*}$ \\
Crotch height & 2.415 & $0.017^{*}$ \\
Kneecap height & 8.347 & $0.000^{*}$ \\
Coat height, standing & 0.788 & 0.435 \\
Span & 9.793 & $0.000^{*}$ \\
Elbow span & 6.012 & $0.000^{*}$ \\
Hip breadth, standing & 1.144 & 0.254 \\
Interscye breadth & 4.884 & $0.000^{*}$ \\
Back waist length & 9.792 & $0.000^{*}$ \\
Sleeve inseam & 2.461 & $0.015^{*}$ \\
Shoulder breadth & 4.209 & $0.000^{*}$ \\
Hip breadth, sitting & 2.133 & $0.034^{*}$ \\
Forearm-hand length & -0.415 & 0.678 \\
Buttock-knee length & 3.920 & $0.000^{*}$ \\
Buttock-popliteal length & -0.163 & 0.871 \\
Shoulder-elbow length & 7.260 & $0.000^{*}$ \\
Thigh clearance & -0.889 & 0.375 \\
Arm reach forwards & 7.560 & $0.000^{*}$ \\
Arm reach upwards & 1.742 & 0.083 \\
Sitting height & 11.981 & $0.000^{*}$ \\
Sitting eye height & 10.018 & $0.000^{*}$ \\
Sitting shoulder height & 9.703 & $0.000^{*}$ \\
Sitting elbow height & 0.076 & 0.940 \\
Knee height & 5.980 & $0.000^{*}$ \\
Popliteal height & 5.265 & $0.000^{*}$ \\
Head length & 3.409 & $0.001^{*}$ \\
Head breadth & 1.905 & 0.059 \\
Hand length & 8.674 & $0.000^{*}$ \\
Fand breadth & 9.764 & $0.000^{*}$ \\
Foot breadth & $0.000^{*}$ \\
\hline Signith & $0.000^{*}$ \\
\hline
\end{tabular}

*Significant at $p<0.05$.

necessity for customised product design and workspaces, even for regional market and populations.

\section{Anthropometric data for sitting and standing industrial workstations}

The industrial workstation is a predominant component in the industrial workplace. Poorly designed workstations contribute to various complications such as visual problems, muscle aches and pains, repetitive trauma injuries such as carpal tunnel syndrome and job stresses [17]. Proper design of the workstation ensures comfort and suitability to the workers. Ergonomic principles and anthropometric database should be used in the design process in order to fit the human to the machines and conditions [18].

Deros et al [17, 19] and Harry [20] described several major anthropometric dimensions critical in designing an industrial table top workstation for sitting and standing tasks. These dimensions are stature, eye height, elbow height, sitting height and sitting shoulder height. For this study, additional dimensions were also considered to highlight the differences in the anthropometric database among the population groups. In total, 10 dimensions were chosen to describe the standing and sitting postures. Figures 1 and 2 show segments proportions for 5th, 50th and 95th percentile of four countries male and female adults in standing posture. There are five selected body dimensions in the standing posture, which are stature, eye height, shoulder height, elbow height with flexed arm and knee height. Similarly, figures 3 and 4 show five body dimensions in the sitting posture, which are sitting height, sitting eye height, sitting elbow height, sitting knee height and sitting buttock to popliteal length.

\section{Discussion}

\subsection{Standing and sitting anthropometry dimension implication to the Malaysian workstation design}

Based on the $t$-test result, there were statistically significant differences in most of the mean dimensions between Malaysian male and female (table 3). There are some dimensions where there is no significant difference such as stature, standing eye height, standing coat height, standing hip breadth, forearm-hand length, buttock-popliteal length, thigh clearance, arm reach upwards, sitting elbow height and head breadth. The result from this study can be considered in designing a proper standing and a sitting workstation that suits the male and female workers. For example, for standing workstations, the table height should be adjustable in the range of $89.4 \mathrm{~cm}$ (5th percentile female standing elbow height) to $112.6 \mathrm{~cm}$ (95th percentile male standing elbow height) while the monitor height should be adjustable in the range of $133.4 \mathrm{~cm}$ (5th percentile female standing eye height) to $167.9 \mathrm{~cm}$ (95th percentile male standing eye height). Meanwhile the dimension of seat length can be the same for both female and male as there is no statistically significant difference in buttock-popliteal length between the male and female.

In the manufacturing line, workers usually remain seated for a long time. Long time spent sitting in bad posture puts an extreme physiological strain on the muscles, the ligaments and in particular on the discs and other health consequences such as cardiovascular disease mortality [21, 22]. A proper sitting workstation will help reduce the risks related to poor ergonomics design such as musculoskeletal stress disorders (MSDs), which result in eye, neck and back strain, fatigue, headache, wrist, hand, elbow and shoulder 
Table 4. The mean anthropometric data for four Asian countries (all dimensions in $\mathrm{cm}$, body weight in $\mathrm{kg}$ ).

\begin{tabular}{|c|c|c|c|c|c|c|c|c|c|}
\hline \multirow[b]{2}{*}{ No. } & \multirow[b]{2}{*}{ Anthropometric measurement } & \multicolumn{2}{|c|}{ Malaysian } & \multicolumn{2}{|c|}{ Indonesian $^{\mathrm{a}}$} & \multicolumn{2}{|c|}{ Filipinos $^{\mathrm{b}}$} & \multicolumn{2}{|c|}{ Thai people $^{c}$} \\
\hline & & Male & Female & Male & Female & Male & Female & Male & Female \\
\hline 1 & Weight & 68.4 & 58.7 & NA & NA & NA & NA & 65.4 & 51.4 \\
\hline 2 & Stature & 168.1 & 155.7 & 172.0 & 159.0 & 167.0 & 153.9 & 168.6 & 157.5 \\
\hline 3 & Standing eye height & 155.5 & 143.1 & 160.0 & 148.0 & 155.0 & 143.1 & 156.4 & 145.8 \\
\hline 4 & Standing shoulder height & 138.5 & 127.6 & 143.0 & 132.0 & 137.5 & 127.2 & 139.6 & 131.1 \\
\hline 5 & Standing elbow height & 103.7 & 96.2 & 107.0 & 100.0 & 104.1 & 96.3 & 107.0 & 98.3 \\
\hline 6 & Waist height & 99.1 & 93.1 & NA & NA & 97.3 & 95.5 & NA & NA \\
\hline 7 & Crotch height & 78.8 & 74.7 & NA & NA & NA & NA & NA & NA \\
\hline 8 & Kneecap height & 47.0 & 42.7 & NA & NA & 49.7 & 45.9 & NA & NA \\
\hline 9 & Coat height, standing & 68.8 & 64.1 & NA & NA & NA & NA & NA & NA \\
\hline 10 & Span & 169.9 & 155.0 & 172.0 & 157.0 & 167.9 & 153.2 & 174.8 & 167.6 \\
\hline 11 & Elbow span & 85.9 & 79.5 & 87.0 & 79.0 & NA & NA & 94.3 & 88.7 \\
\hline 12 & Hip breadth, standing & 37.2 & 32.8 & NA & NA & 43.5 & 43.4 & NA & NA \\
\hline 13 & Interscye breadth & 30.8 & 28.7 & NA & NA & 36.4 & 32.6 & NA & NA \\
\hline 14 & Back waist length & 46.6 & 40.2 & NA & NA & NA & NA & NA & NA \\
\hline 15 & Sleeve inseam & 45.9 & 43.4 & NA & NA & NA & NA & NA & NA \\
\hline 16 & Shoulder breadth & 40.0 & 37.9 & 45.0 & 45.0 & 44.7 & 40.2 & 44.4 & 39.2 \\
\hline 17 & Hip breadth, sitting & 34.3 & 35.3 & 36.0 & 36.0 & 48.5 & 47.7 & 33.7 & 35.0 \\
\hline 18 & Forearm-hand length & 39.5 & 39.8 & 48.0 & 43.0 & 44.1 & 40.5 & 46.3 & 42.8 \\
\hline 19 & Buttock-knee length & 54.4 & 52.5 & 56.0 & 53.0 & 54.8 & 52.7 & 56.1 & 54.9 \\
\hline 20 & Buttock-popliteal length & 43.0 & 43.1 & 46.0 & 43.0 & 46.4 & 45.1 & 48.1 & 44.3 \\
\hline 21 & Shoulder-elbow length & 34.9 & 32.2 & NA & NA & 33.1 & 31.4 & 37.1 & 32.7 \\
\hline 22 & Thigh clearance & 13.1 & 13.4 & 16.0 & 15.0 & 13.5 & 12.8 & 16.4 & 15.1 \\
\hline 23 & Arm reach forwards & 80.9 & 74.2 & NA & NA & 76.6 & 69.6 & NA & NA \\
\hline 24 & Arm reach upwards & 149.6 & 117.9 & NA & NA & 127.9 & 116.9 & NA & NA \\
\hline 25 & Sitting height & 87.7 & 81.5 & 88.0 & 83.0 & 84.8 & 79.9 & 88.9 & 84.7 \\
\hline 26 & Sitting eye height & 76.3 & 70.9 & 76.0 & 73.0 & 73.4 & 68.4 & 76.2 & 73.9 \\
\hline 27 & Sitting shoulder height & 59.3 & 54.5 & 59.0 & 57.0 & NA & NA & 59.1 & 55.8 \\
\hline 28 & Sitting elbow height & 23.1 & 23.1 & 25.0 & 25.0 & 22.2 & 21.9 & 23.4 & 21.7 \\
\hline 29 & Knee height & 50.4 & 47.5 & 54.0 & 51.0 & 50.0 & 47.0 & 47.5 & 45.4 \\
\hline 30 & Popliteal height & 42.4 & 40.0 & 44.0 & 44.0 & 43.3 & 40.3 & 39.2 & 37.0 \\
\hline 31 & Head length & 19.1 & 17.7 & 20.0 & 19.0 & 20.5 & 19.2 & 19.7 & 17.3 \\
\hline 32 & Head breadth & 15.2 & 15.0 & 19.0 & 17.0 & 17.2 & 16.5 & 17.4 & 14.8 \\
\hline 33 & Hand length & 18.3 & 17.0 & 19.0 & 18.0 & 19.8 & 18.0 & 18.4 & 17.3 \\
\hline 34 & Hand breadth & 8.1 & 7.2 & 9.0 & 8.0 & 9.8 & 9.2 & NA & 7.8 \\
\hline 35 & Foot length & 24.7 & 22.7 & 25.0 & 23.0 & 25.4 & 22.6 & NA & 22.6 \\
\hline 36 & Foot breadth & 9.6 & 8.9 & 10.0 & 9.0 & 10.5 & 9.5 & NA & 9.4 \\
\hline
\end{tabular}

${ }^{\mathrm{a}}$ For mean value of Indonesian, the data of 245 male and 132 female were obtained from Chuan et al [14].

${ }^{\mathrm{b}}$ The Filipinos anthropometric database of 1805 workers was obtained from Lu [15]. For Philippines, the 1805 subjects were manufacturing workers in the assembly line, and not the general Filipino population.

${ }^{\mathrm{c}}$ The anthropometric data of 400 participants for Thai people were adopted from Yodpijit et al [16].

diseases and carpal tunnel syndrome [23, 24]. This study presents the recommended dimensions for the sitting workstation design. For sitting height, the seat should be adjustable in the range of $34.0 \mathrm{~cm}$ (5th percentile female popliteal height) to $46.8 \mathrm{~cm}$ (95th percentile male popliteal height). Meanwhile, for designing the sitting working table, the recommended table height should be adjustable in the range of $19.0 \mathrm{~cm}$ (5th percentile female sitting elbow height) to $29.9 \mathrm{~cm}$ (95th percentile male sitting elbow height) and for monitor height, the height should be adjustable in the range of $64.6 \mathrm{~cm}$ (5th percentile female sitting eye height) to $83.5 \mathrm{~cm}$ (95th percentile male sitting eye height).

As a result of rapid increase of world population, the demand for better and more efficient products is growing. Ergonomic workstations are important not only for workers but also for the students and elderly people as the design would help increase comfort, work productivity and performance. Dawal et al [2] highlighted the importance of anthropometric database of high school and university 


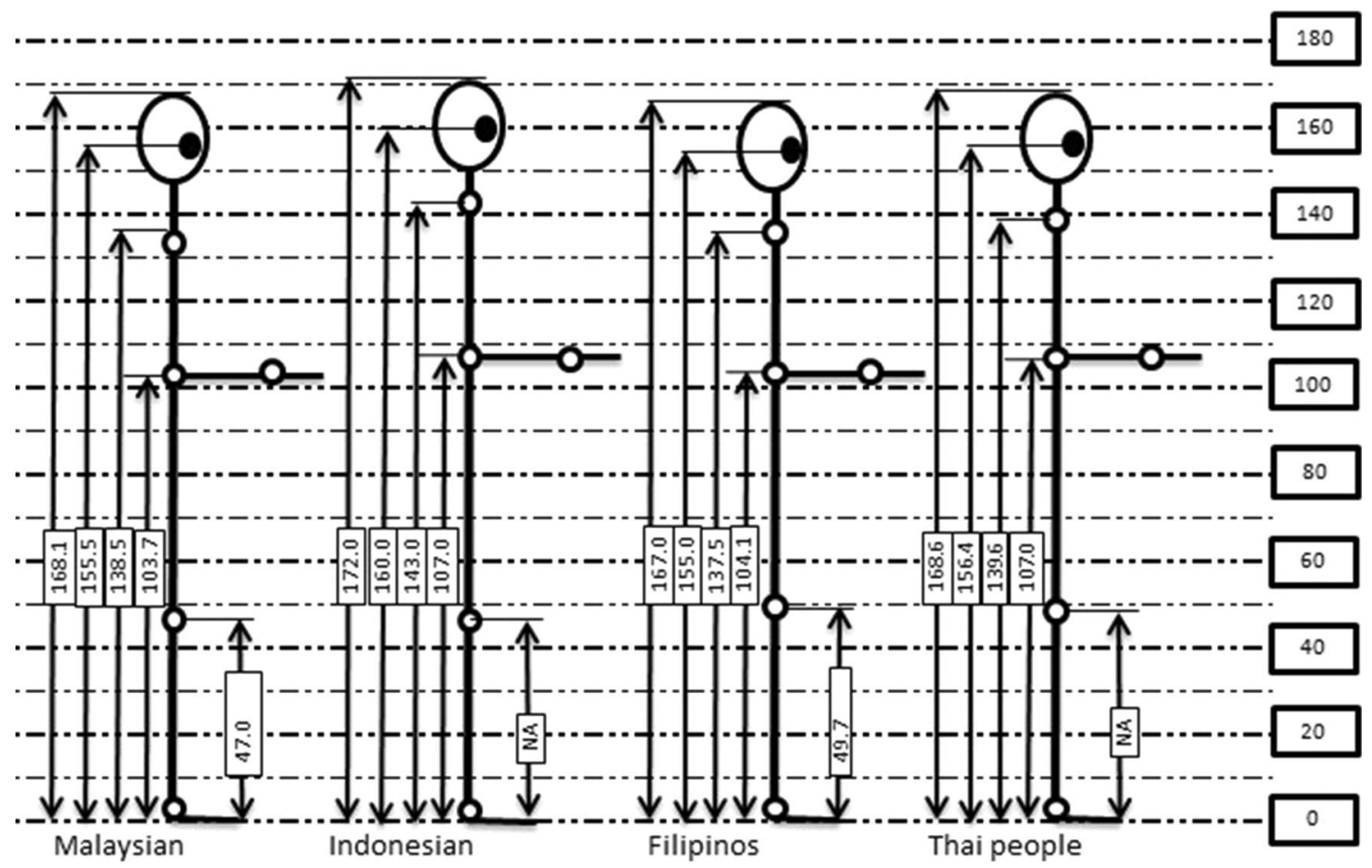

Figure 1. The illustration of segment proportions for Asian male adults in standing posture (all dimensions in $\mathrm{cm}$ ).

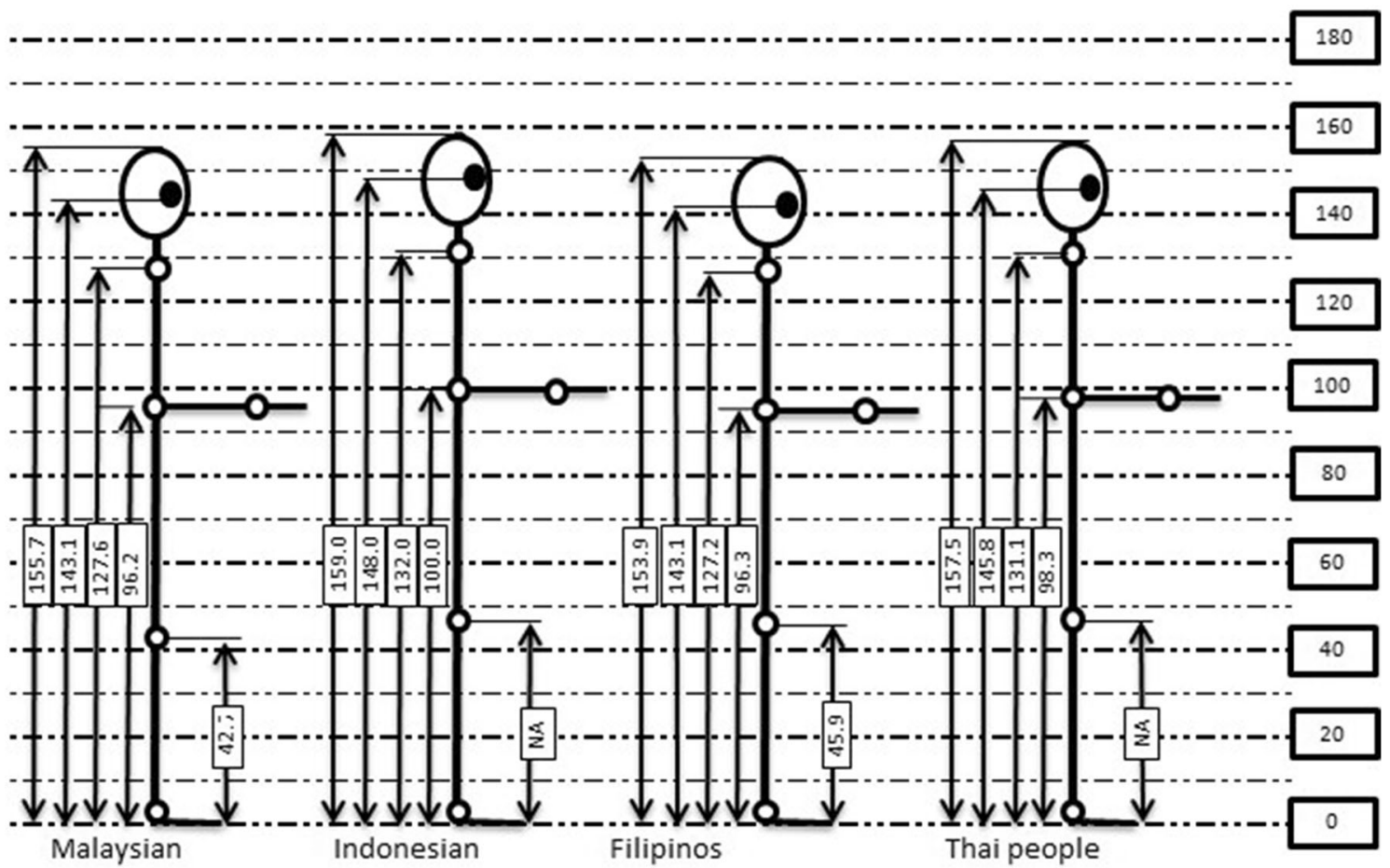

Figure 2. The illustration of segment proportions for Asian female adults in standing posture (all dimensions in $\mathrm{cm}$ ).

students from Malaysia. There were significant differences in anthropometric data between genders for both high school and university students. Musculoskeletal pain can occur if these differences are not considered for workstation designs and selections. Meanwhile, Davari [25] presented a design of home office computer workstation set-up to 


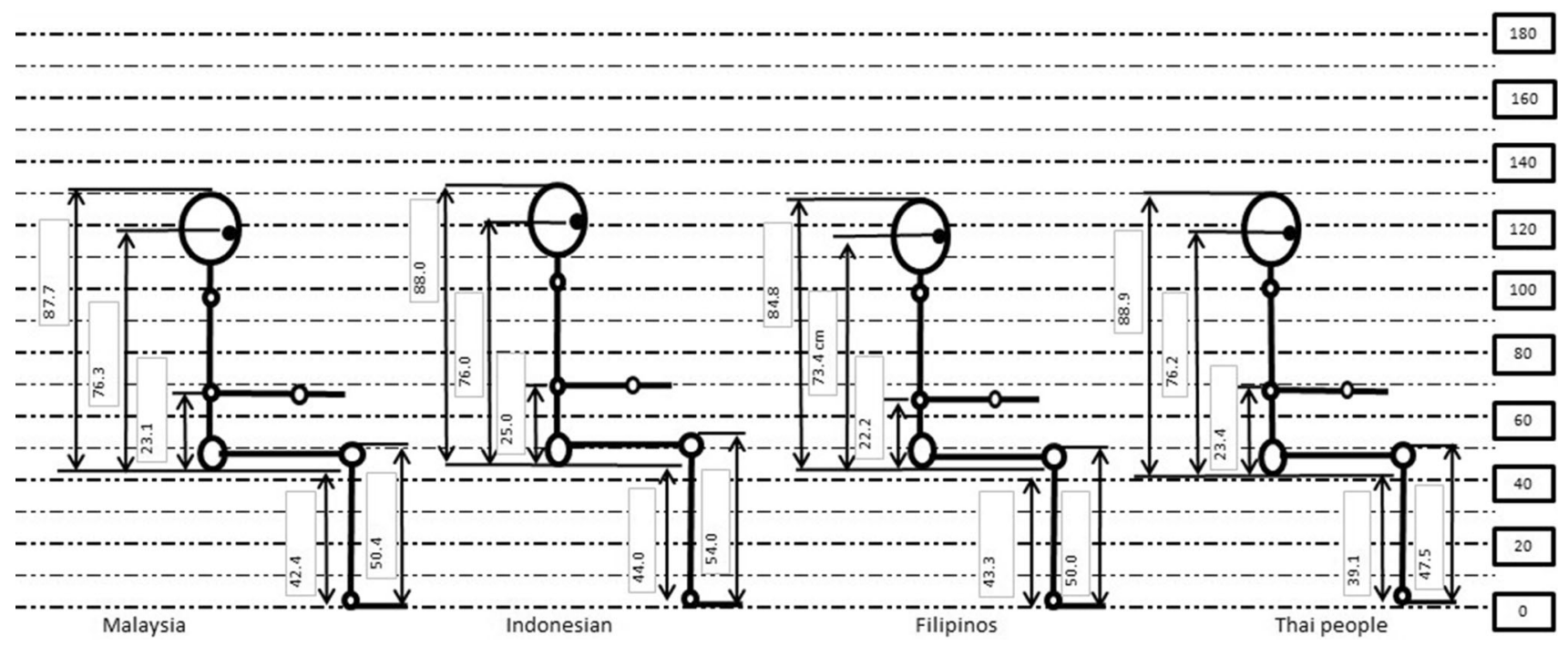

Figure 3. The illustration of segment proportions for Asian male adults in sitting posture (all dimensions in $\mathrm{cm}$ ).

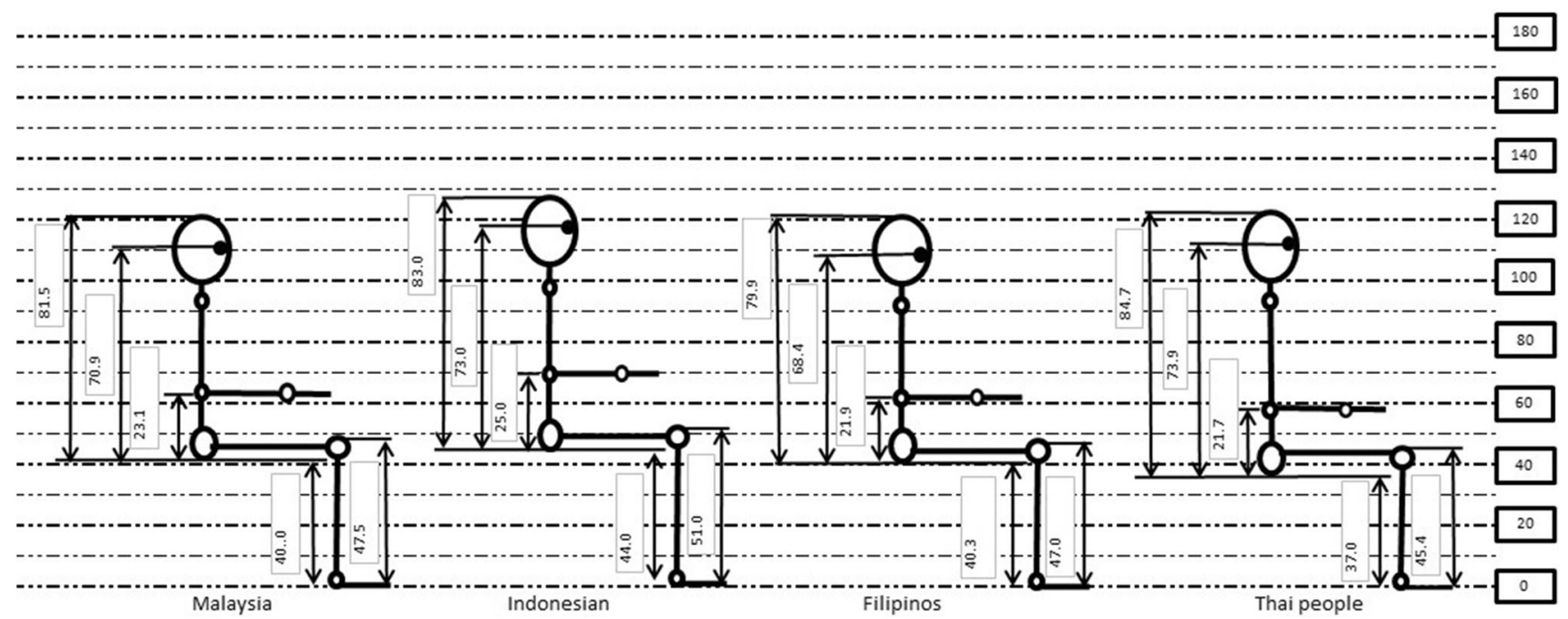

Figure 4. The illustration of segment proportions for Asian female adults in sitting posture (all dimensions in $\mathrm{cm}$ ).

reduce perceived musculoskeletal discomfort. The necessities to be considered in anthropometric data of the design were highlighted to prevent strain injuries, which can lead to long-term disabilities. On the other hand, designing furniture for elderly is undoubtedly important for their survival to live independently in this challenging world [6]. Elderly anthropometric databases assist the designing process in creating a safe and healthy environment for the elderly. Due to economic status and also categories under developing countries, Southeast Asian countries undoubtedly are the centre of attractions for migration purposes. Therefore, the knowledge of variations in the population is useful in designing sound workstations and facilities for the betterment of the environment, especially industrial environment.

\subsection{Comparison of anthropometric data of selected Asian countries}

Anthropometric data from populations of four countries were summarised and compared. In general, it can be seen that the Indonesians were the tallest $(172 \mathrm{~cm}$ for male, $159 \mathrm{~cm}$ for female) among the four countries, whereas the Filipinos were the shortest for both male and female (167 cm for male, $153.9 \mathrm{~cm}$ for female). Indonesians were 
also higher than other populations in several standing body heights, including eye height, shoulder height and elbow height. Filipinos and Malaysia data were almost similar and appear to have the smallest values for eye height $(155 \mathrm{~cm}$ for male, $143 \mathrm{~cm}$ for female) and elbow height (104 cm for male, $96 \mathrm{~cm}$ for female).

The Thai people have the greatest sitting height and sitting eye height for both male and female while Filipinos have the lowest value (sitting height: $84.8 \mathrm{~cm}$ for male, $79.9 \mathrm{~cm}$ for female, sitting eye height: $73.4 \mathrm{~cm}$ for male, $68.4 \mathrm{~cm}$ for female). Accordingly, Malaysian females also appear to have similar low sitting height as Filipinos females. The smallest value for upper limb was for Filipinos male, which is $22.2 \mathrm{~cm}$, and the Thai female, which is $21.7 \mathrm{~cm}$. The Indonesians have the highest value for knee height (54 cm for male, $51 \mathrm{~cm}$ for female) and popliteal height (44 $\mathrm{cm}$ for both male and female). The Indonesian male knee height was the highest, while in contrast, Thai male and female have the smallest mean value for knee height (47.5 cm for male, $45.4 \mathrm{~cm}$ for female).

The selected dimensions illustrated in the figures 1, 2, 3 and 4 are the important reference dimensions for the workstation design that is safe and comfortable. The illustrations compare between male and female of each country. It can be seen that Indonesians and Filipinos have a large difference between the male and female mean stature dimension, which is $13 \mathrm{~cm}$. Standing eye height is also difference between male and female by about $12 \mathrm{~cm}$. Meanwhile, for sitting dimensions illustrated, it can be seen from the figure that there is a difference between Indonesian male and female sitting height, which is about $5 \mathrm{~cm}$. Only small differences are found between the eye height of male and female from each country, such as $2.3 \mathrm{~cm}$ for Thai people and $5 \mathrm{~cm}$ for Malaysian. Based on these findings, it is important to design the standing and sitting workstation (table, chair, working entrance, machine interface, etc.) that fits both male and female body dimension to ensure workers' health and safety, while simultaneously improving their work performance and productivity [19].

\subsection{Recommended chair and desk dimensions for Asian countries}

With reference to the data in table 4 , the mean values of the selected Asian countries were used to develop recommendations and suggestions for designing chair and desk. Figure 5 presents the recommended dimensions for the selected Asian countries. The calculations of the chair's back rest height, seat height, seat width, seat depth and desk height recommended dimensions were based on the equation by Gouvali and Boudolos [26]. The equations are as follows:

backrest height $(B): 0.6 S \leq B \leq 0.8 S$

seat height $(S H):(P+2) \cos 30^{\circ} \leq S H \leq(P+2) \cos 5^{\circ}$

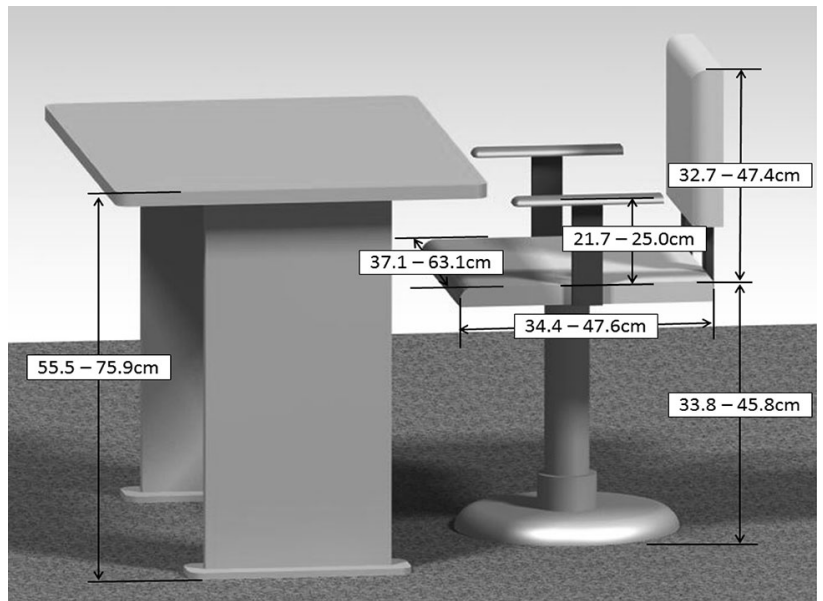

Figure 5. Recommended chair and desk dimensions for Asian countries.

seat width $(S W): 1.1 H \leq S W \leq 1.30 H$

seat depth (SD): $0.80 P B \leq S D \leq 0.99 P B$

desk height $(D): E+\left[(P+2) \cos 30^{\circ}\right] \leq D \leq[(P+2) \cos$ $\left.5^{\circ}\right]+(0.8517 E)+(0.1483 S)$

where $S$ is shoulder height, $P$ is popliteal height, $P B$ is popliteal-buttock length, $H$ is hip breadth and $E$ is elbow height.

The mean value of Malaysian female and male shoulder height was, respectively, the minimum and the maximum value among the four countries and was used in the calculation for the back rest height dimension. The height should be adjustable from 32.7 to $47.4 \mathrm{~cm}$. The adjustable seat height of the chair should be from 33.8 to $45.8 \mathrm{~cm}$. These data were taken from mean of Thai female citizen popliteal height and Indonesian male citizen popliteal height. This will allow the users to place their feet properly on the floor or on a footrest because hanging legs put extra loads on lower back muscles [17]. The seat width was designed to be adjustable from 37.1 to $63.1 \mathrm{~cm}$ from mean value of hip breadth of Thai male and Filipinos male. Meanwhile, seat depth was $34.4-47.6 \mathrm{~cm}$ from mean value of buttock-popliteal length of Malaysian and Thai male. The armrest of chairs was designed parallel to the floor and adjustable from 21.7 to $25.0 \mathrm{~cm}$; these ranges were taken from the mean value of Thai female (minimum) and Indonesian male (maximum). On the other hand, the desk height is adjustable $(55.5-75.9 \mathrm{~cm})$ based on calculation of the minimum and maximum mean value related to sitting elbow and shoulder height and popliteal height among the four countries populations.

\section{Conclusion}

This study was motivated on the need to improve the ergonomics of the industrial environment, particularly in developing countries, where manual operators are 
intensively used. In this study, the anthropometric dimensions for sitting and standing postures for the Malaysian population were identified and developed, and subsequently compared to three Asian counterparts. The results have highlighted several differences in body dimensions. The anthropometric database can be used to design sound industrial workstations and facilities ergonomically. Furthermore, knowing the variations in the anthropometric dimensions enables the designers to anticipate required modifications to their design to cater for other population groups.

\section{Acknowledgements}

This work is financially supported by University of Malaya under the Equitable Society Research Cluster (ESRC) research Grant RP027A-15SBS; and Postgraduate Research Grant (PPP) Grant No. PG1162016A.

\section{References}

[1] Vasquez K, Malhotra R, Ostbye T, Chan M F, Amin H, Khoo G and Thilagaratnam S 2015 Extent and correlates of change in anthropometric and fitness outcomes among participants in a corporate team-based weight loss challenge in Singapore: lose to win 2009. Asia Pac. J. Public Health 27(2): 425-436, https://doi.org/10.1177/1010539512455044

[2] Dawal S Z M, Zadry H R, Azmi S N S, Rohim S R and Sartika S J 2012 Anthropometric database for the learning environment of high school and university students Int. J. Occup. Saf. Ergon. 18(4): 461-472

[3] Klamklay J, Sungkhapong A, Yodpijit N and Patterson P E 2008 Anthropometry of the southern Thai population. Int. J. Ind. Ergon. 38(1): 111-118. http://dx.doi.org/10.1016/j. ergon.2007.09.001

[4] Wang M J, Wang E M Y and Lin Y C 2001 Anthropometric data book of the Chinese people in Taiwan. Taiwan: Ergonomics Society of Taiwan (in Chinese)

[5] Bolstad G, Benum B and Rokne A 2001 Anthropometry of Norwegian light industry and office workers. Appl. Ergon. 32(3): 239-246

[6] Dawal S Z M, Ismail Z, Yusuf K, Rashid S H A, Shalahim N S M, Abdullah N S and Kamil N S M 2015 Determination of the significant anthropometry dimensions for user-friendly designs of domestic furniture and appliances - experience from a study in Malaysia. Measurement 59: 205-215. http:// dx.doi.org/10.1016/j.measurement.2014.09.030

[7] Sanders M S and McCormick E J 1992 Human factors in engineering and design, McGraw-Hill International ed. Singapore: McGraw-Hill Inc

[8] Jamir L, Kalaivani M, Nongkynrih B, Misra P and Gupta S K 2015 Anthropometric characteristics and undernutrition among older persons in a rural area of northern India. Asia Pac. J. Public Health 27(2): 2246-2258. https://doi.org/10. 1177/1010539513490191

[9] Jürgens H W, Aune I A and Pieper U 1990 International data on anthropometry. Geneva: International Labour Office
[10] Pheasant S 1996 Bodyspace: anthropometry, ergonomics and design of work. New York: Taylor \& Francis

[11] Lin Y C, Wang M J and Wang E M 2004 The comparisons of anthropometric characteristics among four peoples in East Asia. Appl. Ergon. 35(2): 173-178. http://dx.doi.org/10. 1016/j.apergo.2004.01.004

[12] Nurul Shahida M S, Siti Zawiah M D and Case K 2015 The relationship between anthropometry and hand grip strength among elderly Malaysians. Int. J. Ind. Ergon. 50: 17-25. https://doi.org/10.1016/j.ergon.2015.09.006

[13] Hu H, Li Z, Yan, J, Wang X, Xiao H, Duan J and Zheng L 2007 Anthropometric measurement of the Chinese elderly living in the Beijing area. Int. J. Ind. Ergon. 37: 303-311. https://doi.org/10.1016/j.ergon.2006.11.006

[14] Chuan T K, Hartono M and Kumar N 2010 Anthropometry of the Singaporean and Indonesian populations. Int. J. Ind. Ergon. 40(6): 757-766. http://dx.doi.org/10.1016/j.ergon. 2010.05.001

[15] Lu J L D P 2007 Anthropometric measurement of Filipino manufacturing workers. Int. J. Ind. Ergon. 37: 497-503. ISSN 0169-8141. http://dx.doi.org/10.1016/j.ergon.2007.02. 004

[16] Yodpijit N, Bunterngchit Y and Lockhart T E 2004 Anthropometry of Thai Technical University students. In: Proceedings of the 2004 IIE Annual Research Conference, Houston, TX, USA

[17] Deros B M, Mohamad D, Ismail A R, Soon O W, Lee K C and Nordin M S 2009 Recommended chair and work surfaces dimensions of VDT tasks for Malaysian citizens. Eur. J. Sci. Res. 34(2): 156-167

[18] Wang E M Y, Wang M J, Yeh W Y, Shih Y C and Lin Y C 1999 Development of anthropometric work environment for Taiwanese workers. Int. J. Ind. Ergon. 23: 3-8

[19] Deros B M, Khamis N K, Ismail A R, Jamaluddin H, Adam A M and Rosli S 2011 An ergonomics study on assembly line workstation design. Am. J. Appl. Sci. 8(11): 1195-1201

[20] Harry C S 2003 Ergonomic factors involved in optimum computer workstation design. St. Paul: Ergotron, Inc., and Constant Force Technology, LLC, available: www.ergotron. com/Portals/0/literature/.../ERGONOMIC_FACTORS.pdf

[21] Haitao Hua Z L 2007 Anthropometric measurement of the Chinese elderly living. Int. J. Ind. Ergon. 37(4): 303-311

[22] Dunstan D W, Barr E L M, Healy G N, Salmon J, Shaw J E, Balkau B, Magliano D J, Cameron A J, Zimmet P Z and Owen N 2010 Television viewing time and mortality: the Australian Diabetes, Obesity and Lifestyle Study (AusDiab). Circulation 121: 384-391, published online before print January 112010. https://doi.org/10.1161/circulationaha.109.894824

[23] Sweere H C 2002 Ergonomic factors involved in optimum computer workstation design: a pragmatic approach. St. Paul: Ergotron, Inc., and Constant Force Technology, LLC

[24] Zairina A R and Sallam A A 2009 Prevalence of work-related upper limbs symptoms (WRULS) among office workers. Asia Pac. J. Public Health 21(3): 252-258. https://doi. org/10.1177/1010539509341423

[25] Davari M 2013 Anthropometric home office computer workstation setup. Gazimağusa, North Cyprus: Eastern Mediterranean University

[26] Gouvali M K and Boudolos K 2006 Match between school furniture dimensions and children's anthropometry. Appl. Ergon. 37(6): 765-773 